\title{
Immunologic Study of the Age-related Loss of Activity of Six Enzymes in the Red Cells from Newborn Infants and Adults - Evidence for a Fetal Type of Erythrocyte Phosphofructokinase
}

\author{
A. KAHN, (44) C. BOYER, D. COTTREAU, J. MARIE, AND P. BOIVIN
}

INSERM U24, Hôpital Beaujon, Clichy, and Institut de Pathologie Moléculaire, INSERM U129, Paris, France

\section{Summary}

Blood from 10 normal healthy adults and cord blood from 8 healthy full term infants were infiltrated through a mixture sulfoethylethycellulose-Sephadex $G 25$ in order to eliminate the platelets and the leukocytes. Then the erythrocytes were fractionated into young and old cells by centrifugation in microhematocrit tubes. The enzyme activity and the immunologic reactivity of glucose phosphate isomerase (EC. 5.3.1.9), phosphoglycerate kinase (EC. 2.7.2.3), pyruvate kinase (EC. 2.7.1.40), glucose 6-phosphate dehydrogenase (EC. 1.1.1.49), and 6-phosphogluconate dehydrogenase (EC. 1.1.1.44) were measured in every fraction.

As previously reported, the enzyme activities were far higher in cord blood than in adult blood red cells; nevertheless, the agerelated loss of enzyme activity was similar in both cord and adult blood. The decrease of the enzyme activity of glucose phosphate isomerase and phosphoglycerate kinase in old cells was singly associated with a lowered concentration of the enzyme-related antigen; by contrast, the age-related decrease of the enzyme activity of pyruvate kinase, glucose-6-phosphate dehydrogenase, and 6-phosphogluconate dehydrogenase was associated with both a lowered concentration of the enzyme-related antigen and a lowered "molecular specific activity" (i.e., a lowered ratio of enzyme activity to enzyme-related antigen concentration). This phenomenon was especially marked for pyruvate kinase, which had a molecular specific activity in old cells that was $68 \%$ of that in young cells.

Phosphofructokinase had a lower enzyme activity in cord blood erythrocytes than in adult blood erythrocytes; the difference was especially important in old cells from infants in which phosphofructokinase activity was $53 \%$ of that in old cells from adults. Phosphofructokinase from old cells of full term infants and from unfractionated cells from two premature infants (21 and 32 weeks of gestation) was less neutralized by anti-muscle phosphofructokinase serum and more inhibited by ATP than the enzyme from adult blood erythrocytes.

\section{Speculation}

The phenomenon of molecular aging of the enzymes in red cells could differ for every enzyme. In some cases molecular aging could lead to degradation of the molecules; these would then no longer be recognizable either by their catalytic activity or by their antigenic properties. In other cases molecular aging could be associated with the inactivation (partial or total) of some molecules which would not be changed with respect to their antigenic properties. These phenomena do not seem to differ in either cord blood or adult blood erythrocytes.

The low enzyme activity of phosphofructokinase in cord blood red cells seems to be a unique feature of the "fetal" erythrocytes and seems to result from the synthesis in the fetal erythroblasts of a "fetal-type" phosphofructokinase. This fetal enzyme could be relatively deficient in the muscle-type subunit which accounts for about $50 \%$ of the activity of the normal phosphofructokinase in adult blood erythrocytes. These data could be involved in the metabolic peculiarities and in the reduced viability characterizing the fetal red blood cells.

It has been well established that the activity of many red cell enzymes decreases progressively with increasing cell age in adults as well as in newborn infants $(1,17,25,35)$. Agedependent alterations have been observed in the catalytic and electrophoretic or electrofocusing properties of some erythrocyte enzymes $(2,6,7,10,19,27,28,29,32-34)$. The decrease of the ratio of enzyme activity to immunologic reactivity in old red cells has been described for two enzymes, aldolase (27) and glucose-6-phosphate dehydrogenase (10). The aim of the present paper is to elucidate the mechanisms of the age-related loss of red cell enzyme activity in the adult and in the infant (either inactivation of the enzyme, or decrease of the enzyme-related antigen, or both).

Erythrocyte phosphofructokinase from newborn infants has been shown to exhibit a peculiar behavior among the other glycolytic enzymes $(17,18,31,39)$ : the activity of phosphofructokinase in the old cells of cord blood is significantly lower than that from the old fraction of adult blood, whereas the activity in the young fractions is similar. The ratio of phosphofructokinase activity of young cells to old cells is thus far higher in cord blood (17). Consequently, in this work we have attempted to determine whether or not fetal phosphofructokinase is qualitatively different from the enzyme of adults, accounting for the low enzyme activity found in the old red cells in infants; in the newborn infant, indeed, the older erythrocytes can be considered to be those produced earlier in gestation, i.e., the "fetal" erythrocytes (17).

\section{EXPERIMENTAL PROCEDURE}

\section{MATERIALS}

The substrates and intermediate enzymes were furnished by Boehringer-Mannheim or Sigma CC. The ampholines came from LKB, acrylamide and bisacrylamide from Eastman-Kodak, and agarose from l'Industrie Biologique Française. Sephadex G25 was provided by Pharmacia, sulfoethylethycellulose (type SE 23 ) by Serva (Heidelberg), and $\alpha$-cellulose and microcrystalline cellulose (Sigmacell type 50) by Sigma CC. The enzymatic assays were measured at $30^{\circ}$ in a Zeiss PMQ II spectrophotometer connected with a Servogor recorder.

\section{METHODS}

Blood Samples and Red Cell Fractionation. Venous blood obtained from 10 normal healthy volunteers and cord blood 
obtained from the placenta of 8 healthy full term infants and of 2 premature infants (21 weeks and 32 weeks of gestation) were anticoagulated with 1:5 volume of acid-citrate-dextrose formula A. Leukocytes and platelets were removed by filtration through a mixture sulfoethylcellulose-Sephadex G-25 (30). Erythrocytes were fractionated in young and old cells by centrifugation in microhematocrit tubes, according to the method of Herz et al. (8). In order to avoid all contamination by leukocytes, the "young fractions" of erythrocytes were further filtrated through a cellulose column, according to the method of Beutler (4). Reticulocytes were counted in each fraction and in the unfractionated red cells.

Enzyme Activity Assays. The enzyme activities were measured according to the methods summarized by Beutler (4). The results were expressed in international units per $g$ of hemoglobin at $30^{\circ}$.

Immunologic Titrations. Erythrocyte glucose-6-phosphate dehydrogenase (13), leukocyte 6-phosphogluconate dehydrogenase (16), leukocyte phosphoglycerate kinase (5), leukocyte $\mathbf{M}_{2}$ type pyruvate kinase $(15,23)$, leukocyte glucose phosphate isomerase (3), and liver L-type pyruvate kinase (24) were purified to homogeneity from human tissues, as previously described. Monospecific antibodies were obtained from rabbits; a monospecific anti-rabbit muscle phosphofructokinase chicken serum (26) was used.

The immunologic reactivity of glucose-6-phosphate dehydrogenase, 6-phosphogluconate dehydrogenase, and glucose phosphate isomerase was measured according to Laurell's technique (20), made more sensitive by specific staining of immunoprecipitate peaks for enzyme activity $(10,11,37)$ (Fig. 1).

Gels were prepared in $25 \mathrm{mM}$ barbital chloride buffer, $\mathrm{pH}$ $8.2,1 \%(w / v)$ agarose, and, for 6-phosphogluconate dehydrogenase only, $1 \%$ "linear" acrylamide for decreasing electroendosmosis (9).

The gels contained, in a total volume of $20 \mathrm{ml}, 100 \mu \mathrm{l}$ of antiglucose-6-phosphate dehydrogenase serum or $125 \mu$ l of anti-6phosphogluconate dehydrogenase serum or $20 \mu \mathrm{l}$ of anti-glucose phosphate isomerase serum. A range of five dilutions was depos-

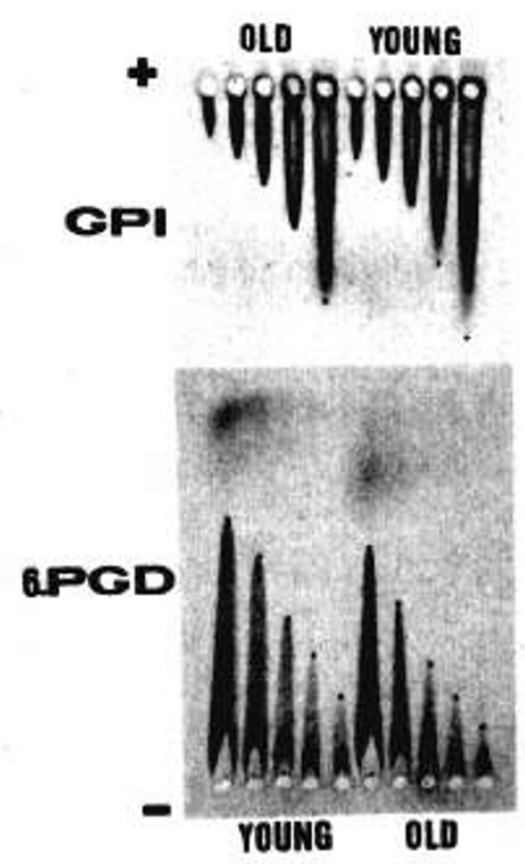

Fig. 1. Electroimmunodiffusion experiment of glucose phosphate isomerase $(G P I)$ and 6-phosphogluconate dehydrogenase (6-PGD) from young and old red cells from a full term newborn infant. The difference between the ratio of hemoglobin $A_{1}$ to fetal hemoglobin in young and old cells can be appreciated on the 6-PGD plate. Details of the method used are given in "Methods."

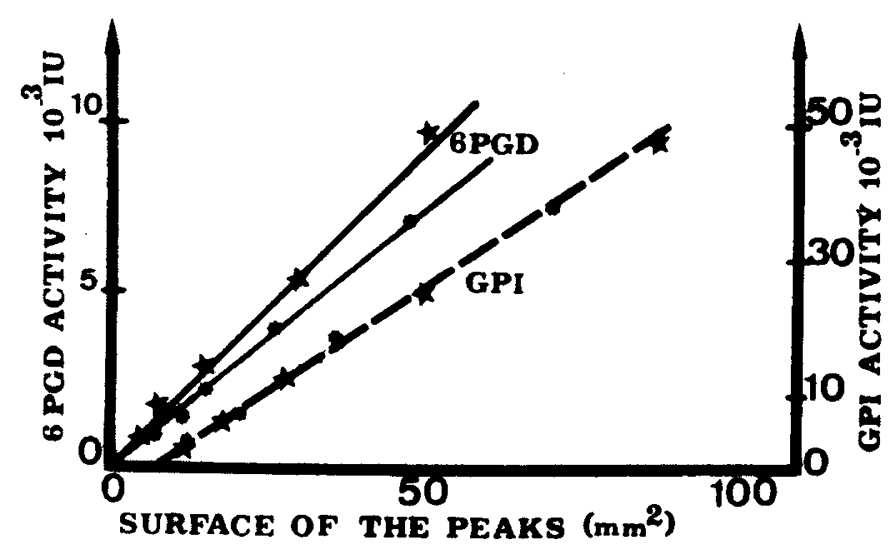

Fig. 2. Graphic representation of electroimmunodiffusion experiments. The slope of the straight line enzyme activity $=f$ (surface of the immunoprecipitate peak) is proportional to the ratio of enzyme activity to immunologic reactivity, i.e., to the "molecular specific activity." $\star--\star 105$ : young cells; $*--*$ : old cells. Molecular specific activity of 6-phosphogluconate dehydrogenase (6PGD) from old cells is lowered with respect to that of young cells, whereas for glucose phosphate isomerase $(G P I)$ this value is unchanged.

ited in 5 - $\mu$ l wells for each extract studied $(1: 2,1: 4,1: 8,1: 16$, and 1:32 hemolysates). Migration ran for $4 \mathrm{hr}$ (glucose-6-phosphate dehydrogenase) or for $2 \mathrm{hr} 30 \mathrm{~min}$ (other enzymes) at $2^{\circ}$ in an electric field of $10 \mathrm{~V} / \mathrm{cm}$ with $50 \mathrm{mM}$ barbital chloride buffer, pH 8.2, as tank buffer. Glucose-6-phosphate dehydrogenase and 6-phosphogluconate dehydrogenase migrated toward the anode and glucose phosphate isomerase toward the cathode. After completion of the run, immunoprecipitate peaks were revealed with the specific appropriate staining mixtures $(3,10,16)$. The surfaces of the immunoprecipitate peaks were measured and plotted on a graph versus enzymatic activities. The slope of the straight line/enzymatic activity $=f$ (surface of the immunoprecipitate peak) represented the ratio of the enzyme activity to its immunologic reactivity, i.e., the "molecular specific activity" (Fig. 2). As the aim of such a measure was to appreciate the agerelated change of "molecular specific activity," the results for the old cells were expressed as a percentage of those found for the young cells.

The immunologic titration of erythrocyte pyruvate kinase (15) and phosphoglycerate kinase (12), as well as the search for $\mathrm{M}_{2}$ type pyruvate kinase activity $(15,23)$, were performed by immunoneutralization according to methods previously described.

Phosphofructokinase was immunologically studied by means of anti-muscle phosphofructokinase serum, as described elsewhere (14).

Study of Inhibition of Erythrocyte Phosphofructokinase by $A T P$. The 1:20 hemolysates were dialyzed for $3 \mathrm{hr}$ in $40 \mathrm{mM}$ Tris- $\mathrm{Cl}$ buffer, $\mathrm{pH} 8$, containing $0.1 \mathrm{mM}$ fructose-6-phosphate, $10 \mathrm{mM} \beta$-mercaptoethanol, $1 \mathrm{mM}$ EDTA, and $1 \mathrm{mM} \epsilon$ aminocaproic acid. In order to eliminate ammonium sulfate, the commercial intermediate enzymes used for the enzymatic reaction were extensively dialyzed against the buffer described above. The reaction was measured at $30^{\circ}$ in a $40 \mathrm{mM}$ Tris- $\mathrm{Cl}$

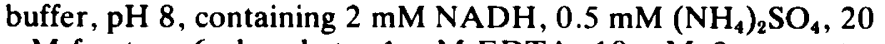
$\mathrm{mM}$ fructose-6-phosphate, $1 \mathrm{mM}$ EDTA, $10 \mathrm{mM} \beta$-mercaptoethanol, $0.5 \mathrm{IU} / \mathrm{ml}$ aldolase, $0.4 \mathrm{IU} / \mathrm{ml}$ glycerol-3-phosphate dehydrogenase, and $1 \mathrm{IU} / \mathrm{ml}$ triose phosphate isomerase. Next, $25 \mu \mathrm{l}$ of dialyzed 1:20 hemolysates were preincubated for 10 $\min$ at $30^{\circ}$ with the reactive mixture, and the reaction was started with various concentrations of ATP- $\mathrm{MgCl}_{2}$ in the ratio of $1: 10$. The final volume of the reactive mixture was $1 \mathrm{ml}$.

Electrofocusing. Glucose-6-phosphate dehydrogenase from old and young cells of newborn infants was focused in acrylamide-ampholine gel, as previously described (10). This permitted 
visualization of the age-related changes in the electrofocusing pattern of erythrocyte glucose-6-phosphate dehydrogenase. The same experiment was also used to compare the ratio of fetal hemoglobin to hemoglobin $A_{1}$, in old and young cells from newborn infants.

\section{RESULTS}

\section{CELL FRACTIONATION}

The mean reticulocyte count was: unfractionated cells, $1.65 \pm$ $0.8 \%$ in adult blood and $6.9 \pm 2.3 \%$ in cord blood; young cells, $6.65 \pm 1.98 \%$ in adult blood and $24.8 \pm 8.8 \%$ in cord blood; old cells, $0.29 \pm 0.14 \%$ in adult blood and $0.73 \pm 0.61 \%$ in cord blood.

The fraction of the young cells was totally devoid of leukocyte contamination in both adult blood and cord blood as judged by a count of Malassez cells or by examination of the blood smears. This was confirmed by the total absence of the leukocytic $\mathrm{M}_{2}$ type isozyme of pyruvate kinase sought by electrofocusing (23) or by inactivation with anti-human, $\mathbf{M}_{2}$-type pyruvate kinase serum (15-23)

The quality of the fractionation in old and young cells from cord blood was also proved by two sets of evidence: the marked predominance of fetal hemoglobin in the old fractions and the $A_{1}$ hemoglobin in the young fractions on the one hand, and the marked age-related shift (10) of the active forms of glucose-6phosphate dehydrogenase on the other (Fig. 3).

\section{ENZYME ASSAYS}

In Table 1 are represented the results of the enzyme assays of the two red cell fractions from adults and infants. In both cord blood and adult blood, pyruvate kinase appeared to demonstrate the greatest decline in activity with aging. By contrast, the activity of glucose phosphate isomerase and, above all, of phosphoglycerate kinase was only slightly lower in old cells than in young ones, in infants as well as in adults. As a matter of fact, the age-related decrease of enzyme activity was of the same order of magnitude in adults and in cord red cells for all the

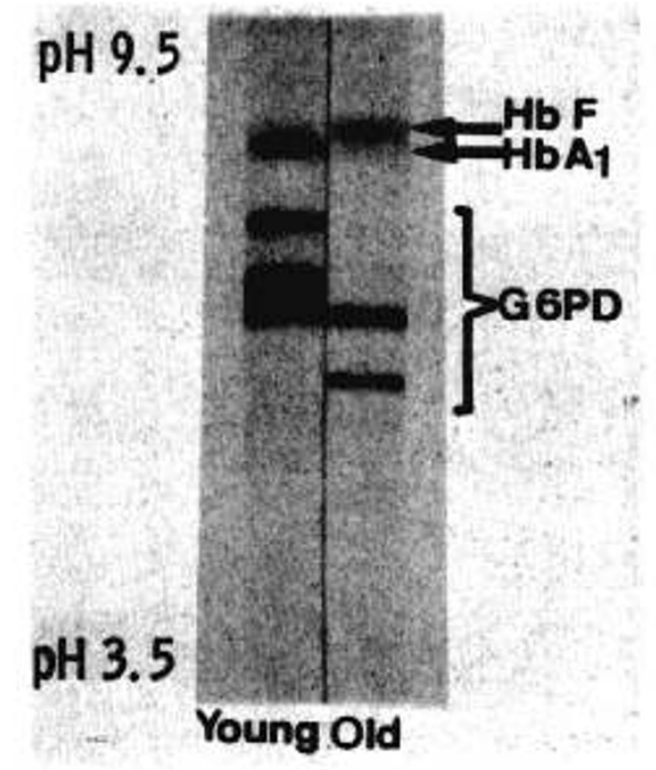

Fig. 3. Electrofocusing in acrylamide ampholine gels of hemolysates from young and old red cells from a newborn infant. The gels were stained specifically for glucose-6-phosphate dehydrogenase activity. $\mathrm{HbF}$ : fetal hemoglobin; $\mathrm{HbA}_{1}$ : hemoglobin $\mathrm{A}_{1}$; G6PD: glucose-6-phosphate dehydrogenase.

Table 1. Enzymatic and immunologic activity of young and old erythrocytes from newborn infants $(n=8)$ and normal adults $(n=10)^{1}$

\begin{tabular}{|c|c|c|c|c|c|c|}
\hline \multirow[b]{2}{*}{ Enzyme and source } & \multirow[b]{2}{*}{$\begin{array}{l}\text { Unfractionated } \\
\text { RBC (enzyme ac- } \\
\text { tivity), IU/g Hb }\end{array}$} & \multirow[b]{2}{*}{$\begin{array}{l}\text { Young RBC (en- } \\
\text { zyme activity), } \\
\text { IU/g Hb }\end{array}$} & \multicolumn{3}{|c|}{ Old RBC } & \multirow[b]{2}{*}{$\begin{array}{l}\text { Enzyme activity } \\
\text { ratio of young/ } \\
\text { old RBC }\end{array}$} \\
\hline & & & $\begin{array}{l}\text { Enzyme activity, } \\
\text { IU/g Hb }\end{array}$ & $\begin{array}{l}\text { Immunologic } \\
\text { reactivity, \% }\end{array}$ & $\begin{array}{c}\text { Ratio of \% en- } \\
\text { zyme activity to \% } \\
\text { immunologic reac- } \\
\text { tivity }\end{array}$ & \\
\hline \multicolumn{7}{|l|}{$\begin{array}{l}\text { Glucose phosphate } \\
\text { isomerase }\end{array}$} \\
\hline Adult & $44.2 \pm 5$ & $55.1 \pm 6$ & $43.8 \pm 5$ & $83.2 \pm 10$ & $100.8 \pm 7.75$ & $1.22 \pm 0.18$ \\
\hline Cord & $65.1 \pm 5.4$ & $81.6 \pm 14.5$ & $61.3 \pm 4.6$ & $74 \pm 10$ & $102.6 \pm 15$ & $1.33 \pm 0.22$ \\
\hline \multicolumn{7}{|l|}{ Phosphoglycerate kinase } \\
\hline Adult & $101 \pm 10$ & $112 \pm 11$ & $103 \pm 10$ & $91 \pm 7.2$ & $97.3 \pm 4.2$ & $1.10 \pm 0.09$ \\
\hline Cord & $152.1 \pm 15.2$ & $173.7 \pm 7$ & $145.6 \pm 16.4$ & $85.5 \pm 9.3$ & $96.5 \pm 6.4$ & $1.2 \pm 0.7$ \\
\hline \multicolumn{7}{|l|}{ Pyruvate kinase } \\
\hline Adult & $10.1 \pm 1.2$ & $20.3 \pm 3.7$ & $8.2 \pm 1.3$ & $61.8 \pm 16$ & $67.9 \pm 9.2$ & $2.48 \pm 0.4$ \\
\hline Cord & $16.4 \pm 2$ & $30.9 \pm 8.5$ & $11.5 \pm 1.2$ & $57.7 \pm 10$ & $68.3 \pm 9.3$ & $2.7 \pm 0.7$ \\
\hline \multicolumn{7}{|c|}{$\begin{array}{l}\text { Glucose-6-phosphate de- } \\
\text { hydrogenase }\end{array}$} \\
\hline Adult & $6.3 \pm 0.7$ & $9 \pm 1.32$ & $5.66 \pm 0.36$ & $76.9 \pm 12$ & $82.9 \pm 15$ & $1.59 \pm 0.28$ \\
\hline Cord & $9.3 \pm 2$ & $12.9 \pm 3.5$ & $7.9 \pm 1.7$ & $77.3 \pm 16.1$ & $79.4 \pm 8.7$ & $1.65 \pm 0.33$ \\
\hline \multicolumn{7}{|l|}{$\begin{array}{c}\text { 6-Phosphogluconate } \\
\text { dehydrogenase }\end{array}$} \\
\hline Adult & $5.3 \pm 0.5$ & $7.3 \pm 0.9$ & $4.75 \pm 0.4$ & $82 \pm 20$ & $82.9 \pm 11.3$ & $1.54 \pm 0.27$ \\
\hline Cord & $6.9 \pm 0.5$ & $10.1 \pm 2.5$ & $6.3 \pm 1$ & $72.9 \pm 14.5$ & $86.8 \pm 7.9$ & $1.6=0.26$ \\
\hline \multicolumn{7}{|l|}{ Phosphofructokinase } \\
\hline Adult & $8.3 \pm 0.9$ & $9.3 \pm 1.3$ & $7.5 \pm 0.9$ & & & $1.22 \pm 0.06$ \\
\hline Cord & $6.2 \pm 0.2$ & $7.5 \pm 0.6$ & $4.0 \pm 1$ & & & $1.73 \pm 0.26$ \\
\hline \multicolumn{7}{|l|}{ Reticulocyte count (\%) } \\
\hline Adult & $1.65 \pm 0.8$ & $6.65 \pm 1.98$ & $\leftarrow$ & $-0.29 \pm 0.14$ & $\longrightarrow$ & \\
\hline Cord & $6.9 \pm 2.3$ & $24.8 \pm 8.8$ & & $-0.73 \pm 0.61$ & $\longrightarrow$ & \\
\hline
\end{tabular}

' Results are given as means $\pm 1 \mathrm{SD}$. Immunologic assays are expressed as a percentage of the values found for the young cells from the same subject studied in the same experiment. RBC: red blood cells. 
enzymes studied except phosphofructokinase; the enzymatic activity was simply higher in infants than in adults.

Phosphofructokinase activity of unfractionated red cells from infants was $75 \%$ of that from adults. That decrease of enzyme activity was mainly due to the low activity in the old cells in which phosphofructokinase activity was $53 \%$ of that from old cells of adults. The ratio of phosphofructokinase activity of young to old cells was thus far higher in cord blood. In unfractionated red cells from the premature newborns, phosphofructokinase activity was $6.0 \mathrm{IU} / \mathrm{g}$ hemoglobin in the youngest infant and $5.9 \mathrm{IU} / \mathrm{g}$ hemoglobin in the older infant (normal value in unfractionated cells from adults: $8.3 \pm 0.9$ ).

\section{IMMUNOLOGIC TITRATIONS}

Immunologic study of the enzymes in young and old cells showed that the decrease of the activity of glucose phosphate isomerase and phosphoglycerate kinase with aging is due to a decrease of the enzyme-related antigen, the molecular specific activity of the enzyme being identical in old and young cells. By contrast, the age-related loss of activity of pyruvate kinase, glucose-6-phosphate dehydrogenase, and 6-phosphogluconate dehydrogenase is due to both the decrease of the enzyme-related antigen and to the decrease of the molecular specific activity of those enzymes: the ratio of pyruvate kinase activity to immunologic reactivity, for instance, is lowered in the old cells to $68 \pm$ $9 \%$ of that in the young cells. This phenomenon is quite similar in adults and infants.

Because erythrocyte phosphofructokinase is a composite made of "muscle type" and of "erythrocyte type" subunits (21, 23-36), it cannot be simply titrated. The immunoneutralization experiments with anti-muscle-type phosphofructokinase serum, however, can give pieces of information about the ratio of the enzyme cross-reacting with that antiserum to total phosphofructokinase.

In adults the neutralization by anti-muscle phosphofructokinase serum did not differ in either old or young erythrocyte fractions. In full term infants, by contrast, phosphofructokinase of young erythrocytes was clearly more neutralized by antimuscle serum than the enzyme of old erythrocytes and, in this respect, did not significantly differ from that of red cells from adults. Compared with the enzyme from adult red cells (young, old, or unfractionated cells), phosphofructokinase from old cells of six full term infants or of two premature infants was markedly less neutralized by the anti-muscle phosphofructokinase serum (Table 2).

\section{INHIBITION OF PHOSPHOFRUCTOKINASE BY ATP}

The inhibition by ATP of phosphofructokinase from old and young cells of adults and from young cells from full term infants was nearly similar in every case. By contrast, enzyme from unfractionated cells of premature infants or from old cells of full term infants was markedly more sensitive to inhibition by ATP (Table 2).

\section{DISCUSSION}

The decrease of enzyme activity associated with molecular aging can result from different mechanisms: (1) the degradation of the molecule which is no longer recognizable, either by its catalytic activity or by its antigenic properties; (2) the partial inactivation of the enzyme molecules; (3) the total inactivation of some of the enzyme molecules, resulting in a mixture of fully active and totally inactive species, all cross-reacting with the specific antibodies.

The first mechanism seems to be the primary one involved in the decrease of the glucose phosphate isomerase and phosphoglycerate kinase activities in old cells. For pyruvate kinase, glucose-6-phosphate dehydrogenase, and 6-phosphogluconate dehydrogenase, the diminution of the enzyme-related antigen accounts for only a part of the loss of enzyme activity, another part being associated with the decrease of the ratio of enzyme activity to immunologic reactivity. Such a decrease of the molecular specific activity can be produced by either of the latter mechanisms put forward above, i.e., by the partial inactivation of the enzyme molecules, or by the mixture of fully active and totally inactive molecules. In previous studies (10), we have demonstrated that glucose-6-phosphate dehydrogenase underwent qualitative changes with aging, associated with a partial inactivation of the enzyme molecules. Similar data have been reported about erythrocyte pyruvate kinase by Paglia and Valentine (32). For 6-phosphogluconate dehydrogenase we cannot choose between these possible mechanisms.

It can be noted that these mechanisms of the loss of enzyme activity with red cell aging were of the same type, qualitatively and quantitatively, in either cord blood or adult blood, except for phosphofructokinase. In newborn infants the "oldest cells" are also those cells which are the most representative of the biochemical processes present in cells produced earlier in gestation (17). It is in these cells that phosphofructokinase activity was most reduced with respect to enzyme from adult red cells. This low phosphofructokinase activity of the oldest cells from newborn babies was associated with a relative defect in the muscle-type phosphofructokinase-related antigen, as proved by the lesser inhibition of fetal phosphofructokinase by antimuscletype phosphofructokinase serum. The same data were found with the enzyme from unfractionated red cells from premature infants.

The hypothesis of the partial defect of the muscle type subunit of the fetal erythrocyte phosphofructokinase was supported by the greater inhibition by ATP of the enzyme from old cells of full term infants or from unfractionated cells of premature infants. It

Table 2. Neutralization by anti-muscle phosphofructokinase (PFK) serum and inhibition of adenosine triphosphate (ATP) of red cell $P F K$ from adult and infant cells

\begin{tabular}{lcc}
\hline & $\begin{array}{c}\text { Neutralization by anti- } \\
\text { muscle PFK serum, } \%\end{array}$ & $\begin{array}{c}\text { Inhibition by ATP } \\
\text { (ATP concentration for a 50\% inhibitor) } \\
\text { mM }\end{array}$ \\
\hline Normal controls $(n=7)$, unfractionated cells & $48 \pm 6$ & $1 \pm 0.2$ \\
Old erythrocytes from full term infants $(n=6)$ & $70 \pm 10$ & $0.4 \pm 0.1$ \\
Unfractionated erythrocytes from one 21-week premature infant & 80 & 0.3 \\
Unfractionated erythrocytes from one 32-week premature infant & 70 & 0.45 \\
\hline
\end{tabular}

\footnotetext{
${ }^{1}$ The neutralization by anti-muscle PFK serum was noted in the conditions reported in Reference 14 , with $4 \mu$ l of antiserum.
} 
has been well established, indeed, that muscle phosphofructokinase is less inhibited by ATP than the enzyme from other tissues $(21,26)$. Moreover, similar data have been described as characterizing the erythrocyte enzyme of the patients with congenital defects of muscle phosphofructokinase $(14,21,22,36,38)$.

The results of our study of the inhibition by ATP of phosphofructokinase from cord blood red cells differ from those reported by Whaun and Oski (39). These authors, however, performed the kinetic studies on unfractionated red cells from full term infants. Since we have demonstrated that the differences with the adult red cell enzyme were noticeable only in the oldest cells of full term infants or in the cells from premature infants (i.e., in the true fetal erythrocytes), this discrepancy is apparent rather than real.

In conclusion, although the levels of erythrocyte enzyme activities are far higher in cord blood than in adult blood, the mechanisms of the loss of enzyme activity of glucose phosphate isomerase, phosphoglycerate kinase, pyruvate kinase, glucose-6phosphate dehydrogenase, and 6-phosphogluconate dehydrogenase are similar: the age-related loss of activity of phosphoglycerate kinase is slight and seems to be associated mainly with a lowering of the enzyme-related antigen concentration. The same phenomenon accounts for the decreased activity of glucose phosphate isomerase in old cells. For the other enzymes (pyruvate kinase, glucose-6-phosphate dehydrogenase, and 6-phosphogluconate dehydrogenase), the lowering of the enzyme activity in old cells is associated both with a diminished concentration of enzyme-related antigen and with a lowered molecular specific activity. This is especially marked in the case of pyruvate kinase.

In contrast with the other enzymes, red cell phosphofructokinase has an enzyme activity lower in cord blood than in adult blood; activity is especially reduced in the oldest cells from full term infants. In those cells and in unfractionated red cells from premature infants, phosphofructokinase is less neutralized by anti-muscle-type phosphofructokinase serum and more inhibited by ATP than the enzyme from adults. The hypothesis that fetal erythrocyte phosphofructokinase is relatively deficient in the muscle type enzyme is put forward.

\section{CONCLUSION}

Human glucose phosphate isomerase, phosphoglycerate kinase, L-type pyruvate kinase, glucose-6-phosphate dehydrogenase, and 6-phosphogluconate dehydrogenase have been highly purified and monospecific antibodies have been developed in rabbits. Phosphofructokinase (PFK) was studied by means of polyvalent anti-human leukocyte PFK serum and anti-rabbit muscle PFK serum.

Erythrocytes from adult controls and cord blood have been fractionated in young and old cells by means of centrifugation in microhematocrit tubes, and both the enzymatic activity and the immunologic reactivity have been measured in these fractions and in the nonfractionated red blood cells.

As previously reported, erythrocyte pyruvate kinase appeared to demonstrate the greatest decline in activity with aging in both the cells of adults and infants: this decline in enzyme activity was due to both the decrease of the antigen concentration and the decrease of the ratio enzyme activity to immunologic reactivity.

A similar phenomenon was found for glucose-6-phosphate dehydrogenase and 6-phosphogluconate dehydrogenase. In contrast, the slight decline of the activity of glucose phosphate isomerase and phosphoglycerate kinase was explained solely by the decrease of the enzyme-antigen concentration.

PFK activity of cord blood erythrocytes was lower than that of adult erythrocytes, and the decline of this activity was much more marked in infants than in adults. Immunologic studies suggested that fetal erythrocytes were deficient in the muscletype subunit of the erythrocyte PFK; the greater inhibition by ATP of PFK from these fetal erythrocytes seems to confirm such a hypothesis.
In conclusion, immunologic methods allow to specify the mechanism of the changes in enzyme activity related to aging or to the passage from fetal-type to adult-type erythropoiesis.

\section{REFERENCES AND NOTES}

1. Allison, A. C., and Burn, G. P.: Enzyme activity as a function of age in human erythrocyte. Brit. J. Haematol., 1: 291 (1955).

2. Bakay, B., Nyhan, W. L., and Monkus, E. St. J.: Change in electrophoretic mobility of glucose-6-phosphate dehydrogenase with aging of erythrocytes. Pediat. Res., 6: 705 (1972)

3. Bertrand, O., Kahn, A., and Boivin, P.: Human leukocyte glucose phosphate isomerase: Purification by affinity elution and immunological study. Biochimie, 58: 261 (1976)

4. Beutler, E.: Red Cell Metabolism; A Manual of Biochemical Methods, Ed. 2 (Grune \& Stratton, New York, 1975).

5. Cottreau, D., Kahn, A., and Boivin, P.: Human granulocyte phosphoglycerate kinase: Total purification by double affinity elution. Immunological studies. Enzyme, 27: 427 (1976).

6. Edwards, Y. H., Hopkinson, P. A., and Harris, H.: Inherited variants of human nucleoside phosphorylase. Ann. Hum. Genet. London, 34: 395 (1971).

7. Fornaini, G., Leoncini, G., Segni, P., Calabria, G. A., and Dacha, M. Relationship between age and properties of human and rabbit erythrocyte glucose 6 phosphate dehydrogenase. Eur. J. Biochem., 7: 214 (1969).

8. Herz, F., Kaplan, E., and Scheye, E. S.: Red cell acetylcholinesterase deficiency in ABO hemolytic disease of the newborn. Clin. Chim. Acta, 36: 537 (1972).

9. Johansson, B. G., and Hjerten, S.: Electrophoresis, crossed immunoelectrophoresis and isoelectrofocusing in agarose gels with reduced electroendosmotic flow. Anal. Biochem., 59: 200 (1974).

10. Kahn, A., Boivin, P., Vibert, M., Cottreau, D., and Dreyfus, J. C.: Posttranslational modifications of human glucose 6 phosphate dehydrogenase. Biochimie, 56: 1395 (1974)

11. Kahn, A., Cottreau, D., and Boivin, P.: Molecular mechanism of glucose 6 phosphate dehydrogenase deficiency. Hum. Genet., 25: 101 (1974).

12. Kahn, A., Cottreau, D., Galand, C., and Boivin, P.: Human erythrocyte phosphoglycerate kinase deficiency: Presence in a deficient patient of a stable variant with lowered catalytic activity. Clin. Chim. Acta, 69: 21 (1976).

13. Kahn, A., and Dreyfus, J. C.: Purification of glucose 6 phosphate dehydrogenase from red blood cells and from human leukocytes. Biochim. Biophys. Acta, 334: 257 (1974)

14. Kahn, A., Etiemble, J., Meienhofer, M. C., and Boivin, P.: Erythrocyte phosphofructokinase deficiency associated with an unstable variant of muscle phosphofructokinase. Clin. Chim. Acta, 61: 415 (1975)

15. Kahn, A., Marie, J., Galand, C., and Boivin, P.: Molecular mechanism of erythrocyte pyruvate kinase deficiency. Hum. Genet., 29: 271 (1975)

16. Kahn, A., Milani, A., Marie, J., Cottreau, D., and Boivin, P.: Human granulocyte 6 phosphogluconate dehydrogenase: Purification by elective elution with $\mathrm{NADP}^{+}$, immunological and kinetic properties. Biochimie, 57 : 325 (1975).

17. Komazava, M., and Oski, F. A.: Biochemical characteristics of young and old erythrocytes of newborn infant. J. Pediat., 87: 102 (1975).

18. Konrad, P. N., Valentine, W. N., and Paglia, D. E.: Enzymatic activities and glutathione content of erythrocytes in the newborn: Comparison with red cells of older normal subjects on those with comparable reticulocytosis. Acta Haematol., 48: 193 (1972).

19. Kwiatkowska, J.: Rabbit reticulocyte phosphofructokinase. Purification and some properties. Biochim. Biophys. Acta, 321: 475 (1973)

20. Laurell, C. B.: Antigen-antibody crossed electrophoresis. Anal. Biochem. 10: 358 (1965).

21. Layser, R. B. Rowland, L. P., and Bank, W. J.: Physical and kinetic properties of human phosphofructokinase from skeletal muscle and erythrocytes. J. Biol. Chem., 244: 3823 (1969)

22. Layser, R. B., Rowland, L. P., and Ranney, M. M.: Muscle phosphofructokinase deficiency. Arch. Neurol., 17: 512 (1967).

23. Marie, J., Kahn, A., and Boivin, P.: Pyruvate kinase isozymes in man. I. Mtype isozymes in adult and foetal tissues, electrofocusing and immunological studies. Hum. Genet., 131: 35 (1976)

24. Marie, J., Kahn, A., and Boivin, P.: L-type pyruvate kinase from human liver: Purification by double affinity elution. Immunological and electrofocusing characterization. Biochim. Biophys. Acta, 438: 393 (1976).

25. Marks, P. A. Johnson, A. B., and Hirschberg, E.: Effect of age on enzyme activity in erythrocytes. Proc. Nat. Acad. Sci. U.S.A., 44: 529 (1958).

26. Meienhofer, M. C., Carayon, P., and Gacon, G.: Les isozymes de la phosphofructokinase humaine. Biochimie, 54: 1399 (1972)

27. Mennecier, F.: Mise en évidence d'un matériel à réaction immunologique croisée (CRM) de l'aldolase dans les hémolysats de globules rouges et de réticulocytes de lapin. C. R. Acad. Sci. Paris, 270: 742 (1970).

28. Mennecier, F., and Dreyfus, J. C.: Molecular aging of fructose biphosphate aldolase in tissues of rabbit and man. Biochim. Biophys. Acta, 364: 320 (1974).

29. Monn, E.: Relation between blood cell phosphoglucomutase isoenzymes and age of cell population. Scand. J. Haematol., 6: 133 (1969) 
30. Nakao, M., Nakayama, T., and Kankura, T.: A new method for separation of human blood component. Nature New Biol., 246: 94 (1973).

31. Oski, F. A.: Glycolytic intermediates and glycolytic enzymes. Pediatrics, 44: 84 (1969).

32. Paglia, D. E., and Valentine, W. N.: Evidence for molecular alteration of pyruvate kinase as a consequence of erythrocyte aging. J. Lab. Clin. Med., 76: 202 (1970).

33. Peters, J., Hopkinson, D. A., and Harris, H.: Genetic and nongenetic variation of triose phosphate isomerase (TPI) isozymes in human tissues. Ann. Hum. Genet., 36: 297 (1973).

34. Rozenszajn, L. A., Kolman, S., Shoham, S., and Gazith, J.: Glucose-6phosphate dehydrogenase isoenzymes in blood cells. Nature, 226: 862 (1970)

35. Sass, M. D., Vorsanger, E., and Spear, P. W.: Enzyme activity an indicator of red cell age. Clin. Chim. Acta, 10: 21 (1964).

36. Tarui, S., Kono, N., Nasu, T., and Nishikawa, M.: Enzymatic basis for the coexistence of myopathy and hemolytic disease in inherited muscle phosphofructokinase deficiency. Biochem. Biophys. Res. Commun., 34: 77 (1970).

Copyright 101977 International Pediatric Research Foundation, Inc.
37. Uriel, J.: Characterization of enzymes in specific immune precipitates. Ann. N. Y. Acad. Sci., 103: 956 (1963)

38. Waterbury, L., and Frenkel, E.: Hereditary nonspherocytic hemolysis with erythrocyte phosphofructokinase deficiency. Blood, 39: 415 (1972).

39. Whaun, J. M., and Oski, F. A.: Characteristics of red cell phosphofructokinase (PFK): Studies of erythrocytes from newborn infants and adults. Clin. Res., 27: 603 (1969).

40. We attest that informed consent was obtained from the adult volunteers and from the parents of infants whose blood samples were used for the present study.

41. This research was supported in part by Grants from INSERM, CRL 76.5.110.1 and ATP 147537.

42. The present address of Dr. C. Boyer is: Laboratoire Central d'Hématologie, Hôpital Bretonneau, rue arpeaux, 75018 Paris (France).

43. Requests for reprints should be addressed to: $A$. Kahn, Ph.D., L'institut de Pathologie Moléculaire, INSERM U129, 24 Rue du Fg St. Jacques, Paris 75014 (France).

44. Received for publication June 29,1976

45. Accepted for publication September $16,1976$.

Printed in U.S.A.

Pediat. Res. 11: 276-279 (1977)

Neonate respiration

resistive loading ventilatory stability

\title{
The Immediate Ventilatory Response to Added Inspiratory Elastic and Resistive Loads in Preterm Infants
}

\author{
RODNEY B. BOYCHUK, MARY M. K. SESHIA, AND HENRIQUE RIGATTO ${ }^{(26)}$ \\ Department of Paediatrics, University of Manitoba, Winnipeg, Manitoba, Canada
}

\section{Summary}

We measured the changes in tidal volume, duration of the various phases of the respiratory cycle, and peak nasal pressure during elastic and resistive loading in preterm infants. Values were calculated during the first loaded breath, when chemical drive was unchanged. Tidal volume decreased by equivalent percentages with resistive loads of 400,900 , and $2,400 \mathrm{~cm} \mathrm{H}_{2} \mathrm{O}$ / liter/sec, and elastic loads of $330,1,000$, and $3,000 \mathrm{~cm} \mathrm{H}_{2} \mathrm{O}$ liter. Infinite load was also applied (nasal occlusion). Inspiratory duration (Ti) was prolonged during resistive loading, as compared with elastic loading $(P<0.05)$. Changes in expiratory duration (Te) were not different with both loads $(P>0.05)$. Total duration of the respiratory cycle (T), however, tended to increase in relation to control, more so with resistive loads. Peak nasal pressure was greater with resistive than with elastic loads $(P<0.025)$. We suggest that (1) preterm infants, like adult subjects and other animal species, increase inspiratory duration with resistive loads as compared with elastic loads; (2) $T$ of the first loaded breath tends to increase with progressively larger loads and, consequently, instantaneous frequency tends to decrease; and (3) if peak nasal pressure reflects tension developed by the respiratory muscles, then the latter does not offer the inhibitory information needed to terminate inspiration.

\section{Speculation}

Preterm infants are obligatory nose breathers. Upper airway obstruction, being common in these infants, would impose extra resistive load on respiration. Because the pattern of breathing is more affected by resistive than elastic loading, it may be that an understanding of the physiologic response to resistive loads is more important than that obtained with conventional emphasis on elastic loading.

The ability of the respiratory system to resist a change in tidal volume in response to added inspiratory loads has been used as an index of ventilatory stability $(11,15)$. There are a number of studies assessing this ability in adult subjects and animals $(4,8$, $9,17,19-21)$, but few in neonates $(1,12,13)$. Furthermore, little is known about the response to elastic and resistive loads in the same subjects $(6,16,17)$. In preterm infants such a re- 